\title{
ERRATUM
}

\section{Casein compositional studies. 1. The composition of casein from Friesian herd milks}

BY J. GERARD BARRY AND WILLIAM J. DONNELLY

Journal of Dairy Research Vol. 47 (1980), 71-82, page 77, Fig. 3.

Top (right): For Month, herd 2 read Month, herd 1.

Bottom (left): For Month, herd 1 read Month, herd 2. 